\title{
HINDU-MUSLIM RELATIONS AND BRITISH POLITICS: THE EMERGENCE OF POLITICAL LEADERSHIP IN SOUTH ASIA
}

\author{
Ghulam Shabbir \\ Lecturer, Department of History \& Pakistan Studies \\ University of Gujrat, Gujrat, Pakistan. \\ ghulam.shabbir@uog.edu.pk \\ Azmat Ullah \\ Assistant Professor, Department of History \\ Government College University, Faisalabad, Pakistan \\ azmat.wzr@gmail.com \\ Khizar Jawad \\ Assistant Professor, Department of History \\ FC College University, Lahore, Pakistan. \\ khizarjawad@fccollege.edu.pk
}

\begin{abstract}
This research paper presents the historical background of Hindu-Muslim relations from their early period to the arrival of Europeans. It's an apotheosis of the social, cultural, and religious relations of the two communities, which from centuries living together and finally decided to partings of the ways. It also manifests the acme of Hindu-Muslim cooperation before the arrival of the western forces in India; especially the British. It is a brief analysis of the two prominent communities of India, the Hindu, and the Muslims. Further, it also emphasized on the factors which led these both communities towards the detestable environment. Which later became the prime reason for the Hindu-Muslim communalism and both nations living on together for hundreds of years were ready to part their ways. In this bitterness, the role of the British policy 'divide and rule' is also highlighted.
\end{abstract}

Key Words: Hindu-Muslim Relations, Muslim Invaders in India, British Policy of Divide and Rule, Modern Education.

\section{INTRODUCTION}

\section{INTERACTION OF HINDU-MUSLIM KINGS}

Long before Islam Arabs had trade relations with India and after the advent of Islam, they preached their religion through trade interaction. The second phase of this collaboration started in the $7^{\text {th }}$ century, with the start of military campaigns in eastward. On the issues of prisoners Islamic State had some apprehensions with Raja Dahir (663-712 A.D), His kingdom was conquered by Umayyad forces, and he was killed in the Battle of Aror at the bank of river Indus near modern days Nawabshah, the last ruler of Brahmin dynasty. The Eastern theatre of war was in the meantime moving under Muhammad bin Qasim (695-715 A.D), belonged to the Saqifi clan of the Taif area, the father of Qasim, Qasim bin Yousaf, died when he was young. His paternal uncle Hijaj bin Yousaf, a notorious governor of Umayyad, played an important role in the learning of Qasim, especially in the art of war and governance of a state. Before the conquest of Sindh, Qasim was married to the daughter of Hijaj, her name was Zubaidah, in 710 he was advancing with considerable Army, 'of which 6000 were Syrian, this son of law of al-Hajjaj subdued Makran, pushed on through what is now termed Baluchistan and in 711-712 reduced Sind' (Hitti, 2002). Qasim also conquered the seaport of Daybul and in 713, extended his conquest as far north as Multan in south Punjab. This led to the permanent occupation of Sindh and Southern Punjab, but the Umayyad dynasty did not enhance their extension policy in the East. After this invasion, 'the rest of India remained unaffected until the close of the tenth century, when a fresh invasion begin under Mahmud of Ghaznah (971-1030)' (Hitti, 2002). 


\section{MUSLIM INVADERS AND HINDU-MUSLIM RELATIONS}

Qasim gave the Hindus all privileges as per the roles of Sharia and set up a precedent for Muslim rule. Arab-Indian celebration had stated the momentum as the Arabs were custodian of the realm and their defence, they appointed Hindu officer (Amils) to look after the areas and their main responsibility was to maintain the civil administration (Ikram, 1997). Later, Abbasid Dynasty succeeded these areas in 750 A.D and continued the policy of Qasim, the Arab Indian collaboration. Both Indian-Arab communities enhanced their collaboration in the field of intellectual and cultural growth. Some 300 years after the Arab conquest of Sindh, the capital Sultan Mahmud Ghaznavi, Ghazni, was emerged as the prime political, cultural, and military hub. He was a man of many dimensions. He was a king, an administrator, soldier, undefeatable campaigner, and a prodigious benefactor of the art \& sciences. He acquired recognition as an Idol-Breaker and invaded Hindustan for seventeenth times, extracting a large amount of Indian for his splendid capitate, Ghazni, in Afghanistan. S. M. Ikram argues in the same vein about Mahmoud, he mainly ruined the prosperity of India, and wonderfully exploited the Hindus' rifts to manage his control of a vast territory, and he became able to disperse the Hindu influence and unity. In his way he didn't face a major impediment in his military campaigns towards India (Ikram, 1964).

The era of Mahmoud was a bad dream for the Hindus and the destruction of Somnath remained for many centuries in the Hindu mind (Thapar, 1979). He was the first Muslim in the Subcontinent who adopted the title of Sultan. He decided to turn his famous city into his capital and the city was the Ghazni, which most of area covers Afghanistan, Pakistan and eastern, this capital became luxurious by looting the riches and wealth of Hindustan Sub-continent (Saunders, 1947). In 1020 Mahmud annexed the multicultural city of Lahore. He introduced Persian as the official language of the state which mostly remained as official langue during the Muslim rule in India (Ikram, 1997).

The successors of Mahmoud could not maintain his legacy and finally, Ghazni was captured by Muhammad Gauri in 1186 A.D. He was defeated in the Battle of Tarain, which was fought near the town of Tarain in 1191, now it's part of Haryana, which is $150 \mathrm{KM}$ from the north of Indian capital Delhi. The forces of Sultan led by his famous commander Mu'izz al-Din and the forces of Chauhan Rajput commanded by the Pirthvi raj Chauhan. The next year 1192, on the same battlefield he defeated an Alliance of Rajput's commanded by Prithviraj the dominion now extended to the bank of the Ganges (Ahsan, 2009).

It was the commencement of the new epoch in India and after a few years later, Qutb-ud-Din Aibak (1150-1210) established the Muslim rule in 1206 A.D. Sultan exhibited mercy for his indigenous Indian subjects, he erected mosque with the material of Hindu temples (Lamb, 1967). Ibn Battuta (1304-1369), a renowned Muslim traveller, came in India during the fourteenth century. He wrote a comparative account on the Hindu and Muslims, he observed that both communities live together with limited social interaction. Hindus were following old religious customs; no Muslim was allowed to enter in their houses and not allowed to use their vessels. If a non-Hindu used their vessels for eating purpose, either they broke it or give it to him (Ikram, 1964). Ibn Battuta witnessed the judicial system of the Muslim Empire in India and chronicled it in his account. Further, he narrated, 'in India complaints were also registered; but no registration fees were demanded by the complainant, nor he required to employ the Vakil. When Hindus suit a case against the emperor the case was registered in the Qazi's Court. Whence issued summon against the His Majesty and the later attended' (Battuta, 1976). The Muslims ruled India from 712 to 1857. These years were full of good and bitter realities. The deterioration of the Muslims was a real challenge to survival. The traditional Indian society was based upon caste membership which was essential for social interaction. The caste consciousness among the Hindus remained unbroken and Islam in India could not change it (Hutton, 1961).

The Timur's (1336-1405) incursion of India in 1398-99 opened the destiny to consolidate the Mughal dynasty in 1526. Some modernise Hindus and Muslims attempted to harmonize their relation with the set-up of equality, fraternal love and virtue (Shrikant, 2008). Many of the leaders like Bhagat Kabir (1440-1518), Guru Nanak (1469-1539) and Dadu Dayal (1544-1603) emphasized common features between Hindus and Islam, but the commonly held view that Bhakti was entirely a syncretic movement is wrong (Ikram, 1997). Another attempt was made by Mughal King Akbar (1542-1605) for the coalescence of Hinduism and Islam. The religious orthodoxy of both classes showed a great antipathy over it and precluded the amalgamation of Islam and Hinduism. Mughal Akbar as engrossed 
a new scheme of religion for his own political benefits, he tried to examine the common elements of Indian religions, especially Islam, Christianity, and Hinduism. This debate of his new religious policy started in 1575 and ended in 1582 (Vincent, 1917).

The era of Aurangzeb Alamgir (1618-1707) widened the gulf between Hindus and Muslims. He re-imposed poll-tax, an Islamic tax on non-Muslims in a Muslim state, which intensified the hostility among the non-Muslims (Truschke, 2017). His conduct with Sikhs of the Punjab and their religious Gurus was quite controversial. He served India for 49 years, but he was failed to win the heart of Hindus. Being the last greater Mogul ruler, he could not manage the legacy of Babar and Akbar. After his era that hostility was transformed into the deterioration of the Mughal rule (Ali, 2001).

The era of the later Mughals was the moral and political decline of Muslim rule. The attack of Persian King Nadir Shah (1688-1747) on Indian soil, in 1739 added fuel to the fire. He looted and plundered the Mughal Capital, Delhi. He had not even a soft corner of his contemporary ruler of India. His famous biographer Mortimer Durand illustrated; The Mughal King came to the Persian camp for the peace settlements. He had to face a worse humiliation from his Muslim counterpart (Durand, 1908). He marched away bearing with priceless Peacock Throne and immense booty in gold. Mischievously he seized the diamond Koh-i-Noor in exchange for turbans with Muhammad Shah Rangila (1702-1748). It glittered in his turban and later on glittered 'in the crown of the British King' (Durand, 1908).

In 1761 Ahmad Shah Abdali (1722-1772) followed the repeated invasions in India against Mughals and Hindu Marathas. Perhaps the primary reason, why Islam and Hinduism failed to accomplish social amalgamation despite their acquaintances extending over a thousand years, is that they represent such widely divergent religious views. In some parts of India, Hindus and Muslims shared a common cultural heritage, especially, in Bengal, Punjab and Orissa. The two groups influenced each other positively, such as dress, food, social manners, language, art, literature, and particularly architecture (Srivastava, 1964). Hindu-Muslim's lack of understanding of each other's religion and culture dispensed no give and take in the real sense. The mutual impact on both civilizations was lasting for centuries, but living together in the same land they could not 'learn from each other for their mutual benefits' (Srivastava, 1964). Muslims in India consisted primarily of conversion from Hinduism. Most of the conversion happened due to the upper cast hierarchy of the Hindu caste system.

Muslim attitude towards Hindus prior to the British subjugation of India, there is also substantiation of tolerance and cooperation between Hindus and Muslims. In 1608 King James I sent William Hawkins to the court of Mughal King Jahangir for the approval of permanent factories on Indian soil. Later on, in 1612, he sent Sir Thomas Roe to arrange the commercial treaties with Jahangir (Lawson, 2013). It was the commencement of the Indo-Anglo relations and proved vicious to the Muslim rule in India.

The East India Company had a lasting impact on Indian history. Later, Company was changed from trading to political power in India. The company first haunted Nawab of Bengal, Sirag-udDaulah (1733-1757) and forces against him were sent from Madras. These forces were under the leadership of Clive and Admiral Watson. In January 1757 they captured Calcutta and on 23 June Clive experienced the greatest success of all in his military career, with the defeat of the Nawab's forces at Battle of Plassey (Lawson, 2013). In Nawab's defeat, Mir Jafar played an imperative role and he was resentful with the appointment of a Hindu as prime Diwan, Mohanlal (1756-1757) (Sanyal, 1990).

The Hindu-Muslim upper class was not ready to accept the supreme legitimacy of each other in authority. After the exact hundred years of Battle of Plassey there was a historical incident, which transformed the face of Indian politics, named as Mutiny or War of Independence, (Jalal, 2004) abruptly started with the rebellion of Bengal Army at Meerut on $11^{\text {th }}$ May, 1857 (Willaims, 2006). It exhibited the temporary Hindu and Muslim unity, later, changed into hostility.

The noteworthy Hindu leaders who played an indispensable role in the war of Independence were Nana Sahib (1828-1857) Peshwa of Maratha Empire, Rani Laxmi Bai (1828-1857) Queen of the princely state Jhansi, Tantia Tope (1814-1859), real name was Ramchandra Panduranga, commander of the rebels (Ahmud, 1994), a galaxy of Hindu revolutionaries along with Muslim counterparts endeavoured to expel the East India Company from India (Holmes, 1883). The revolutionaries had 
control of Delhi for four months and four days. Bahadur Shah Zafar (1775-1862), the last Mughal Emperor of India, being a Muslim created no problems for his Hindu Army (David, 2009). The Bengal Army of the Company was consisting of 60 to 65 per cent of Hindus and the remaining 40 to 35 per cent was Muslims etc.

All the revolutionary forces belonged to the different religions and classes, had no issue fighting under the leadership of Bakht Khan, the commander of the Mughal Army. After the brutal suppression of the rebellion, the discourse of acrimony, hostility and hate towards the faith between Hindu and Muslims was created by the British. It was the beginning of the "Divide and Rule Policy" of the British Raj. For example, before the British rule in India there was not major clash between Hindu and Muslims had reported. Moreover, it mostly happened in the last dying days of the British rule in India (Dutt, 1970).

Jabez T. Sunderland, an American Unitarian minister and reformer, paid two lengthy visits to India, first in 1895 and second in 1913, observed the Indian situation and supported the Indian Freedom Movement. He expressed the American sentiments in one of his notable works, the British rule in India had an impression the American minds as good and almost unqualified good. They believed that the British never tire of "pointing with pride" to what they had done for the betterment of India and Indian society. American had all information through the British sources and they haven't any other independent source of information, and majority of the Americans had no information about the other side of the story (Sunderland, 1928). The Hindu-Muslim rivalry, widely believed that, was a created phenomenon. Moreover, he argues about the situation of Hindu-Muslim relations, as two separate communities which had the religious and social differences almost had some feelings of hostility. Apart from it both had the collaboration and corporation in every sphere of life, especially both communities. Mainly it was the British policies and politics which turned these two sister communities into the adversaries, and this situation led towards the Hindu-Muslim clashes and later on, many protuberant riots were reported all around the country (Sunderland, 1928).

Same as Pakistani distinguished writer and theorist of freedom movement of Pakistan. He was a strong devotee of "Two Nation Theory" F. M. Khan Durrani recounted, it was a fact that the riots between Hindu and Muslims, before the British rule in India, were not found as major element in Indian history. It all started to momentum in the end of $19^{\text {th }}$ century, and it was the result of British policies. Although, these riots were limited and reported in far areas of the state. It became a integral part of British Empire in 1923 and this was the beginning of a disaster (Durrani, 1944).

During Mutiny the British newspapers reported cooked up stories to the reader and reporters reported wrong information. Karl Marx, one of his articles, entitled "The Revolt in India", published in New York Daily Tribune on 18 September 1857 and he criticised the British journalists as, the information which we received yesterday was very frightening and catastrophic aspect of British rule in India. But the correspondents to the British press from India hiding the major story from the British masses. The news and information about the 29 July incidents were fully covered under the British iron-hands (Marx, 1959).

It was the British policy to propagate the social and theological difference between Hindus and Muslims. The British policies regarding the communal crises in India had infuriated the Hindu and Muslims in the $3^{\text {rd }}$ decade of the $20^{\text {th }}$ century. A British Scholar S. H. Philips pointed out this resulted in the contrast of two religions. So this comparative analysis of Hinduism and Islam had added the fuel to fire in an orthodox Indian society (Philips, 1948).

Later, the British response towards communalism instigated a new policy "divide and rule" to neutralise the pressure against imperialism. Gandhi narrated, no one could trace out the fact that Hindu and Muslims were remain at war in history. Further he added, this Hindu-Muslim hostility emerged with the advent of British rule in India (Gandhi, 1963).

\section{HINDU-MUSLIM RELATIONS AND BRITISH COLONIALISM}

The East India Company became the ruling power in Bengal in 1765; they met a system of 'indigenous education system', based on traditional knowledge (Ghosh, 1989). Hindus and Muslims had their own educational systems lasting for centuries, based on classical and spiritual rather of practical nature (H. Sharp, 1920). Their educational systems suffered a setback because of political turmoil and a lack of a strong centralised political authority (Purkait, 1992). The Charter of the Company, 1813, was the turning point in the history of Indian education. 
The Education of the Indian people was included within the duties of the Company (S. Nurullah, 1943). There was no educational institution for girls and they used to educate at home (Ghosh, 1989). The modern education system was established at the cost of the indigenous education system. The colonial benefits formed the new educational policies of India. Arthur Howell argues about the colonial interest in India as, British Government in India fully ignored the modern education for Indians, they considered it as a hazard for their newly established rule. Later on, introduced an erroneous system of education which was only to accomplish the British agenda in India (Howell, 1872).

In Charter categorically defined the amount of one lakh rupees spend on education. Ironically, British Government could not decide that the medium of instruction would be in English or native languages. This new policy was full of ambiguities, flaws, and obscurities, not clear it would be available for all or privileged classes. These flaws were later addressed by Lord Macaulay in his famous Minute, $2^{\text {nd }}$ February 1835 . He pronounced, this amount of one lakh rupees only spent on the reviving literature in Hindustan, but also had a plain to introduce the knowledge of science in the British colonies, especially in India to counter its traditional educational system (H. Sharp, 1920). He rejected the Indian Languages and declared English as key to the modern sciences and literature. On the eve of the new educational policy, Indians were in fear and had some apprehensions about their oriental knowledge and traditional institutions. They had assumed that the British modern education could convert their children to Christianity. One of the main reasons for antagonism to modern education in India, Hindus and Muslims felt their religions were in danger. Furthermore, he added in his Minute:

We must at present do our best to form a class of persons, Indian in blood and colour, but English in taste, in opinions, in morals and in intellect (Chand, 2007).

After the War of Independence, 1857, the general policy of the East India Company towards the Muslims was based on discrimination and replacing the Muslims with Hindus wherever possible. The Hindus remained loyal to the Company and benefited for a long period of time. Later on, they were dreaming to rule over India through modern democracy (Chawla, 2011). After the War of Independence, under the Government of India Act 1858, the Queen nationalized the Company. Following these events, the British Government tried to introduce the institution of democracy based on the Westminster model, aimed at conscripting the support of loyalists among the Indians. Indian National Congress, with prior approval of the Liberal Prime Minister Gladstone, as an outcome of the situational factor, came into being in 1885 under the leadership of Allan Octavian Hume (1829-1912), a political reformer, ornithologist and botanist (Sitaramayya, 1947). He is considered as the father of Indian Ornithology.

Another step was taken, the introduction of English education into India, with the powerful support of Raja Rammohan Roy (1774-1833), father of the Indian renaissance and modern India, he abolished the ritual of Sati, child marriage and promoted western education in India, among Indians and Thomas Babington Macaulay (1800-1859) among the Englishmen, it was set at rest in favour of English education as against education in Indian languages and literature (Sitaramayya, 1947). Rammohan being highly educated, felt strongly in favour of modern education along western lines (Krishnaiyya, 1969). He transformed medievalist Indian thought and life. Rammohun's gigantic intellect, enriched by encyclopaedic erudition, informed by rational humanism and a universal outlook, all converged to power synchronously a renaissance and a reformation (Tagore, 2016). He started a movement named Brahmo Samaj, founded in 1828 at Kolkata, under this movement on August the 28th, 1828; the first Theistic Church of modern India was founded. At the outset, it was called simply Brahma Sabha, the Society of God (Bradley, 1910). This movement revolutionized the Indians and Indian society.

After it, they became able to demand press freedom, self-rule, basic rights, and political autonomy. However, after the failure of the War of Independence, Muslims were failed to sanctuary their social, educational, and political legacy. On 30 May 1871, Lord Mayo, the Viceroy of India, asked a prominent civil servant, Dr Sir William Hunter (1840-1900), he was a Scottish historian, statistician, member of Indian Civil Services and founded The Imperial Gazetteer of India in 1869, to study the Muslim situation. His study published in 1871, entitled: The Indian Musalmans: Are They Bound in Conscience to Rebel Against the Queen? Was limited in its objectives and based on the 
Imperialistic approach. He raised questions on the loyalty of the Muslims to the British Government. He articulated his views in the dedication of his work on $23^{\text {rd }}$ June 1871:

In these pages, I have tried to bring out in clear relief the past history and present requirements of a persistently belligerent class-of a class whom successive Governments have declared to be a source of permanent danger to the Indian Empire (Hunter, 1871).

He declared Indian Wahhabism as synonymous with Mutiny. Further, he added, about the social and economic condition of the Muslims, "There is now scarcely a Government office in Calcutta in which a Muhammadan can hope for any post above the rank of porter, messenger, and filler of ink-pots and mender of pens" (Hunter, 1871). All new vacancies were snatched away from the Muslims and bestowed, mostly, to the Hindus. In Calcutta Government officially mentioned in the advertisement, "the appointments would be given to none but the Hindus" (Hunter, 1871). His work added fuel to fire and raised dissatisfaction among the Muslims. Sir Syed Ahmad Khan (1817-1898) wrote the review of his work in 1872 and corrected his mistakes (Ahmad, 1872). Syed criticised his methodology and reviewed it as:

Dr. Hunter expressly states that it is only the Bengal Muhammadan to whom he applies the subject-matter of the book, and that it is only them whom he knows intimately. The book, however, abounds in passages which lead the reader to believe that it is not merely the Bengal Muhammadan that the author treats of, but the Muhammadan throughout India (Ahmad, 1872).

After the Mutiny Government had decided to neglect the Muslims in the state's affairs and shares. It substantiated as a disastrous factor for the Muslims and they not only "economically crushed, but educationally and socially also their position was deliberately depressed by the Government" (Asoka Mehta, 1942). The atrocities of the Muslims were at their peak and their sufferings were ruthless. Muslims were waiting desperately for rescue from their situation and a proper guider like Rammohan Roy. In this worst situation, there was a man, Sir Syed Ahmad Khan, who dared to take a step for the betterment of his community. In 1857, he was considered a competent Government official and he was spent almost twenty years in the judiciary. He started a modern educational movement, named the "Aligarh Movement," for the Muslims. He adopted the method of loyalty with the British and set some vital objectives as:

The object of the Aligarh movement was not merely to bring about the modernization of the Muslims of India. Its main object was to make them, as a community, play a dominant role in the religious, political, economic, and cultural life of the country, as their 'forefather' had played for several centuries in the past. For this purpose, it was essential to introduce them to the Western system of education and civilization besides imparting them knowledge of Islamic theology, history and culture, and to assiduously cultivate the friendship and loyalty of the British rulers of India (Jain, 1965).

To bring the Muslims towards modern education was a hard nut to crack. For this utmost task, Syed was the right choice. He was a literary, courageous, well discipline, audacious and composed man. The Muslims resisted the imposition of the British educational system. As a result, they face a miserable condition and economic development in India clearly favoured the Hindus. The Mughal nobility had formed the most part of the Muslims and consisted of lawyers, officer corps, and artisans suffered a great deal (Maddison, 1971). The British disposed of them from the position of power and singled them out for the deliberate repression (Hunter, 1871). They began to be reconciled to the system of education and the British rule with the tireless efforts of Sir Syed.

It was too late, and they lagged generations behind the Hindus in terms of education, literacy, employment, and professional experience. Indeed, by the time educated Muslims began to seek positions, the Hindus were well entrenched in the new set-up (Mathur, 1980). After the War of Independence to 1905, this Era was one of the Hindu-Muslim separateness and Sir Syed suggested the Muslims to stay away from the Congress. The British electoral representative principal in India was in favour of the Hindus and reinforced their dominance over the Muslims (Hayat, 2008). Sir Syed tried to convince the British that the Congress was not a representative body of the whole India, and this denial was also the denial of one nation. They also repudiated subjecting under the Hindu majority rule. Sir Syed argued that the interest of the Muslims separated from the Hindus and could be secured by a separate group (Muhammad, 1976). 
Both the communities remained divided and distant towards each other during this phase. From 1905 to 1912 India was dominated by the thoughts of Bal Gangadhar Tilak (1856-1920) and other Hindu revivalists. Tilak promoted the Hindu religious militancy, religious antagonism and alienation of the Muslims (Noorani, 2010). Swami Dayanand (1824-1883) and Lala Lajpat Rai (18651928) started a Hindu reform movement, Arya Samaj, founded on 10 April 1875, with emphasis on 'Back to the Vedas'. The literature of Bankim Chandra Chatterjee (1838-1894), the composer of 'Vende Matram', a writer, novelist, poet, and journalist from Bengal, was promoted to use Hindu symbols and lore. These acts of revival and reforms enlightened the Hindu community, but prompted feelings of insecurity among the Muslims.

\section{CONCLUSION}

The major political incident of this phase was the partition of Bengal, which took place on 16 Oct 1905 , on the demand of the Governor of Bengal, the main reason behind this partition was to manage the province from the administration point of view. On the visit of King Empower, it was annulled in 1911, which open hostility between Hindus and the Muslims. It was the primary objective of the British 'Divide and Rule' policy. The partition had intended to divide the Hindu-Muslim community in East and West Bengal. The Viceroy of India, Lord Curzon (1859-1925), vindicated partition in the House of Lords in February 1912. In his speech, he stated the partition, "an administrative device to tackle the administrative problems of the province which had become far too unwieldy" (Sayeed, 1968). However, the British Government couldn't sustain against the Hindu pressure and propaganda, and King George V announced the annulment of the partition, on the eve of Delhi coronation on 12 December, 1911 (Hayat, 2008). It was also a turning point in the relations of Hindus and Muslims. The annulment of the partition increased the bitterness in their relations.

The feelings of insecurity among the Muslims deepened and they decided to safeguard their rights through political means and decided to establish their own party, the All-India Muslim League, 1906. Muslims, later, emerged as a third new force in India. The British policies and system in India affected the Indian communities, especially Hindus and Muslims. Both communities were associated with the race of modern education for their survival in the British system. Definitely, it modernised the Indian communities as per the emerging standards in the world communities. It became the prime reason to develop the Indian minds to think about their political leadership. It became possible to adopt the modern methods of world politics which were emerging in the developed communities in the west. In this process, the role of the moderate families in India played an astonishing role to develop the new phenomenon of political leadership.

\section{REFERENCES}

Ahmad, S. S. (1872). Review on Dr. Hunter's Indian Musalmans: Are They Bound in Conscience to Rebel Against the Queen? . Banaras: Medical Hall Press

Ahmud, S. J. (1994). Pillars of Modern India. New Delhi: Ashish Publishing House.

Ahsan, A. (2009). The Indus Saga: And The Making of Pakistan. Lahore: Royal Book Company, .

Ali, M. A. (2001). The Mughal Nobility Under Aurangzeb. New Delhi: Oxford University Press

Asoka Mehta, A. P. (1942). The Communal Triangle in India Allahabad: Kitabistan.

Battuta, I. (1976). The Rehla of Ibn Battuta Translated by Mahdi Hussain. Baroda: University of Baroda.

Bradley, F. B. ( 1910). Twelve Men of Bengal Kolkata: S. K. Lahiri and Co.

Chand, J. (2007). Education in India during British Period New Delhi: Anshah Publishing House.

Chawla, M. I. (2011). Wavell and the Dying Days of the Raj. Karachi: Oxford University Press.

David, S. ( 2009). The Bengal Army and the Outbreak of the Indian Mutiny. Bengal: Manohar Publisher.

Durand, M. ( 1908). Nadir Shah. London: Archibald and Co.

Durrani, F. K. K. (1944). The Meaning of Pakistan. Lahore: S.H. Muhammad Ashraf.

Dutt, R. P. ( 1970). India Today. Calcutta: Manisba.

Gandhi, M. K. (1963). The Way to Communal Harmony, ed. U. R. Rao. Ahmedabad: Navajivan Publishing House.

Ghosh, S. C. (1989). Education Policy in India since Warren Hastings. Calcutta: Naya Prokash. 
H. Sharp, J. A. R. (1920). Selections from Educational Records. Ed. Vol. I, . Calcutta: Superintendent of Government Printing.

Hayat, S. (2008). The Charismatic Leader. Karachi: Oxford University Press.

Hitti, P. K. ( 2002). History of the Arabs. Palgrave Macmillan: New York.

Holmes, T. R. E. (1883). A History of the Indian Mutiny. London: W. H. Allen \& Co.

Howell, A. (1872). Education in British India Prior to 1854 and in 1870-71. Calcutta: Superintendent of Government Printing.

Hunter, W. W. (1871). The Indian Musalmans: Are They Bound in Conscience to Rebel Against the Queen? London: Trübner and Co.

Hutton, J. H. (1961). Caste in India. London: Oxford University Press.

Ikram, S. M. (1964). Muslim Civilisation in India. New York: Columbia University Press,.

Ikram, S. M. (1997). Modern Muslim India and the Birth of Pakistan. Lahore: Institute of Islamic Culture.

Jain, M. S. (1965). Aligarh Movement: Its Origin and Development 1858-1906 Agra: Sri Ram Mehra $\&$ Co.

Jalal, S. B. A. (2004). Modern South Asia: History, Culture, Political Economy London: Rutledge.

Krishnaiyya, G. N. (1969). Raja Rammohan Roy. New Delhi: Natinal Council of Educational Research and Training.

Lamb, B. P. (1967). India: A World in Transition New York: Praeger.

Lawson, P. ( 2013). The East India Company: A History London: Routledge.

Maddison, A. (1971). Class Structure and Economic Growth: India and Pakistan Since the Moghuls. New York: W. W. Norton.

Marx, K. (1959). The Indian Revolt, in Karl Marx and Friedrich Engels, The First Indian War of Independence 1857-1859, ed. . Moscow: Foreign Language Publishing House.

Mathur, Y. B. (1980). Growth of Muslim Politics in India Lahore: Book Trader.

Muhammad, S. (1976). Sir Syed Ahmad Khan: A Political Biography. Lahore: Universal Books.

Noorani, A. G. (2010). Jinnah and Tilak: Comrades in Freedom Struggle. Karachi: Oxford University Press.

Philips, C. H. (1948). India London: Hutchinson's University Library.

Purkait, B. R. (1992). Milestones in Modern Indian Education. Kolkata: New Central Book Agency.

S. Nurullah, J. P. N. (1943). History of Education in India during the British Period. New York: The MacMillan Company.

Sanyal, N. (1990). Rupmanjri (Bengali). Kolkata: Dey's Publishing.

Saunders, K. (1947). A Pageant of India. London: Oxford University Press

Sayeed, K. b. (1968). Pakistan the Formative Phase Karachi: Oxford University Press.

Shrikant, P. (2008). Knowing Guru Nanak. Bombay: Pustak Mahal.

Sitaramayya, P. (1947). The History of the Indian National Congress, Vol. II, . Bombay: Padma Publication.

Srivastava, A. L. (1964). Medieval Indian Culture. Agra: Shiva Lal.

Sunderland, J. T. (1928). India in Bondage Her Right to Freedom. Calcutta: R. Chatterjee.

Tagore, S. ( 2016). Builders of Modern India: Raja Rammohan Roy New Delhi: Publication Division.

Thapar, R. (1979). A History of India, Vol. I. New York: Penguin Books.

Truschke, A. ( 2017). Aurangzeb: The Life and Legacy of India's Most Controversial King. California: Stanford University Press.

Vincent, S. A. (1917). Akbar: The Great Mughal Oxford: The Clarendon Press.

Willaims, C. (2006). A Companion to 19th Century Britain London: John Wiley \& Sons. 